\title{
Důchodová reforma v ČR
}

\section{Roman Beňovský, Michaela Boháčková, Anna Jadrná, Petra Kratochvílová}

\author{
Vedoucí práce: Ing. Lenka Švecová, Ph.D.
}

\section{1. Úvod}

Tak jako mnoho zemí světa, i Česká republika se v budoucnu bude potýkat se stárnutím svého obyvatelstva. Stárnutí způsobí, že současné špatně nastavené důchodové systémy nebudou moci plně uspokojit nároky budoucích důchodců. Bude ubývat obyvatel v produktivním věku a zároveň přibývat lidí v důchodovém věku.

V roce 1990 bylo téměř $9 \%$ světové populace starší než 60 let, do roku 2030 podle dostupných odhadů tento počet vzroste až na $16 \%$. V České republice podle nedávných prognóz vzroste průměrný věk obyvatel ze 40 let v současnosti na 48 let v roce 2065. Podíl občanů starších 65 let vzroste $\mathrm{z}$ dnešních 14 \% na 30 \%. Růst počtu osob v důchodovém věku je zapříčiněn zejména zkvalitňující se zdravotní péčí, díky které se zvyšuje průměrný věk mužů a žen, a také nízkou porodností žen (v ČR 1,19 dětí na jednu matku). Zvyšuje se též průměrný věk prvorodiček, který v současnosti dosahuje 28,2 roku. Stárnutí populace vede $\mathrm{k}$ úbytku plátců sociálního pojištění, ze kterého jsou vypláceny důchody, a zároveň vede k růstu počtu osob, kteří tento důchod pobírají. Nejhůře jsou na tom vyspělé země, ale také mnoho rozvojových zemí.

Hlavním problémem současných důchodových systémů je zejména nedostatek peněz. Tím, že vzroste počet osob v důchodovém věku, budou vzrůstat i výdaje na jejich důchody. Současně poklesnou př́jmy na tyto důchody vlivem poklesu počtu produktivního obyvatelstva. Výdaje na důchody jsou součástí mandatorních výdajů SR, tedy těch, které stát musí povinně vydávat, a které v roce 2005 tvořili $51,2 \%$ z celkových státních výdajů. Největší podíl těchto mandatorních výdajů tvoří sociální transfery domácnostem $(79,3 \%)$, jejichž nejvyšší položku pak tvoří výdaje na důchody. Druhým problémem je zkvalitňování lékařské péče, při které dochází k neustálému prodlužování délky života, ovšem za cenu zvyšování nákladů na léčbu jednoho jedince.

Cílem této seminární práce je vybrat vhodnou variantu reformy důchodového systému pro Českou republiku, pro kterou je stávající systém dlouhodobě neudržitelný. V jednotlivých kapitolách podáváme obraz o současném důchodovém systému a o důvodech pro jeho změnu, o demografickém vývoji obyvatel v ČR a př́klady důchodových systémů ve světě. V závěrečné kapitole jsou uvedeny návrhy důchodových reforem, které budou zhodnoceny pomocí metod manažerského rozhodování. 


\section{Systémy sociálního zabezpečení}

\subsection{Druhy penzijního systému}

\subsubsection{Př́spěvkově definovaný penzijní systém (defined contribution)}

Tento systém předem definuje výši příspěvku, kterou účastníci, zaměstnavatel nebo stát odvádí, teprve pak se stanový výše dávek, které je možné vyplácet. Přesná výše dávek není předem známa, představuje tolik, kolik lze v systému dosáhnout v závislosti na odvedených i budoucích předpokládaných př́spěvků, a také v závislosti na vývoji demografických a ekonomických parametrů. Pozitivní vývoj demografických a ekonomických parametrů znamená lepší dávky, v opačném př́ípadě jejich zhoršení. Změnám parametrů jsou účastníci vystaveni při odchodu do důchodu. Systém má jednodušší způsob výpočtu než dávkově definovaný systém.

\subsubsection{Dávkově definovaný penzijní systém (defined benefit)}

Předem definuje výši př́ispěvku, kterou účastníci mají pobírat, teprve pak se stanoví potřebná výše odvodů. Typická je pro něj existence závislosti mezi vyměřenými dávkami a jejich velikostí na demografických a ekonomických parametrech. Kolísání demografických a ekonomických parametrů poci ují více účastníci v aktivním věku než penzisté. Má složitější způsob výpočtu.

\subsubsection{Hybridně definovaný penzijní systém}

Jedná se o kombinaci příspěvkově a dávkově definovaného penzijního systému. Výše příspěvku předepsána jako $\mathrm{v}$ př́íspěvkově definovaném penzijním systému, zatímco výše doplňovacího př́spěvku zaměstnavatele v účastníkův prospěch dopočtena podle dávkově definovaného systému s cílem dosáhnout předepsané výše dávek. Systém penzijního připojištění v České republice je příspěvkově definovaný, ale dovoluje výjimku spočívající $\mathrm{v}$ tom, že v případě invalidní penze lze použít dávkově definovaný př́stup.

\section{Způsoby financování důchodového systému}

\subsection{Průběžný systém financování (pay-as-you-go)}

V tomto systému jsou příspěvky plynoucí od aktivních účastníků okamžitě přerozděleny a vyplaceny mezi oprávněné poživatele dávek dle jejich okamžitých nároků. Nevytvářejí se žádné fondy, jde pouze o přerozdělení financí. Systém spoléhá na solidaritu mezi generacemi (dnešní aktivní účastníci financují dnešní penzisty) a je velmi náchylný na demografický vývoj. Jedná se o nejrozšîréenější způsob financování na světě.

\subsection{Fondový systém financování}

Představuje fond, sloužící k pokrytí všech tedy i budoucích závazků penzijního plánu. Důraz kladen na investiční činnost penzijního plánu a dosahovanou kapitálovou výnosnost. Klasickým př́ikladem jsou penzijní fondy. 


\section{Charakteristika současného důchodového systému v ČR}

Pro současný systém v ČR je charakteristická sociální solidarita (př́ijemce peněz jiný než plátce), průběžné financování, povinný systém (po splnění stanovených podmínek) pro všechny ekonomicky aktivní osoby (možná i dobrovolná účast v systému), náhrada př́ijmu ve stáří (starobní důchod), invaliditě (plný nebo částečný invalidní důchod) a úmrtí živitele (vdovský, vdovecký a sirotčí důchod). Jedná se o dávkově definovaný dvousložkový penzijní systém, zahrnuje důchodové pojištění ( $28 \%$ z hrubé mzdy) a dobrovolné penzijní připojištění jako dobrovolný doplňkový systém zabezpečení ve stáří, jehož princip je založen na smluvním vztahu mezi občanem a penzijním fondem. Systém je jednotný a dynamický.

\section{Předurčení systému}

Vzhledem k minulým režimům a dlouhé době vlády sociálních demokratů lidé nemají zájem, aby se stávající důchodový systém nějak měnil. Je to zapříčiněno zejména dlouhou dobou, po kterou důchody zajiš oval pouze stát.

Nedávné výzkumy firmy Factum Invenio zadané Ministerstvem práce a sociální věcí ČR ukázaly, že celá polovina obyvatel považuje systém za nespravedlivý. Jedni ho považují za prŕliš solidární, zejména vysokoškolsky vzdělaní lidé a lidé bydlící ve velkých městech, druzí ho považují za prŕliš výkonově orientovaný.

Občané většinou chtějí znát základní obecné informace o stanovení výše důchodu a zvyšování věku odchodu do důchodu. Chybí jim informace o možnosti dalšího spoření, zejména $\mathrm{v}$ penzijních fondech. V neposlední řadě se domnívají, že nejsou dostatečně vysvětlena pravidla a nemají přehled o naspořených prostředcích.

Občané chtějí, aby státem vyplácený důchod tvořil více než dvě třetiny jejich př́ijmů v důchodu. Část by měla pocházet z penzijního připojištění a životního pojištění a zbytek př́ípadné úspory. Je tedy patrné silné spoléhání na státní důchodový systém. Povinná účast ve státním důchodovém pojištění by měla být zachována a je považována za centrální a nenahraditelnou součást důchodového systému.

Penzijní připojištění využívají pouze dvě pětiny obyvatel, životní pojištění jedna čtvrtina, a to i přesto, že mají možnost dostat př́spěvek od svého zaměstnavatele. Tyto formy spoření na důchod jsou spíše využívány jako výhodná forma spoření volných prostředků. Zároveň lidé systém často považují za nedůvěryhodný.

\section{Nevýhody současného systému}

Nevýhodami současného systému jsou zejména citlivost na demografické změny, systém neodráží stárnutí obyvatelstva, pokles relativní výše důchodu při stárnutí obyvatelstva, snižování individuální odpovědnosti občanů, nahrazování přirozené mezigenerační solidarity anonymitou, možnost vládních selhání, návyk obyvatel na pohodlný systém či velké výdaje ze SROV. 


\section{Výhody současného systému}

Výhodami systému jsou např. jeho štědrost či fakt, že systém generuje nejméně chudých důchodců.

\section{Demografie České republiky}

\subsection{Demografický vývoj v ČR a další prognózy vývoje}

$\mathrm{V}$ této kapitole se budeme zabývat demografickým vývojem obyvatel ČR a prognózami jeho dalšího vývoje. Následující údaje pocházejí z projekce obyvatelstva vypracované Českým statistickým úřadem.

Jak je z následujícího Grafu 1 zřejmé, v následujících letech dojde k výraznému nárůstu obyvatel starších 65 let. Tato hodnota stoupne ze 14,1 \% v roce 2005 na 31,3\% v roce 2050, což je více jak zdvojnásobení této hodnoty. Počet dětí do 14 let klesne o téměř jednu šestinu z $14,5 \%$ v roce 2005 na $12,4 \%$ v roce 2050 . Současně v těmito dvěma jevy dojde k poklesu obyvatel v produktivním věku ze $71,3 \%$ v roce 2005 na $56,3 \%$ v roce 2050, což představuje více jak pětinový pokles. Tento vývoj je zapříčiněn nízkou mírou porodností a vysokou pravděpodobností přežití , tzn. nízkou úmrtností.

\section{Graf č. 1: Vývoj složení obyvatel ČR podle hlavních věkových skupin v letech 2005-2050}

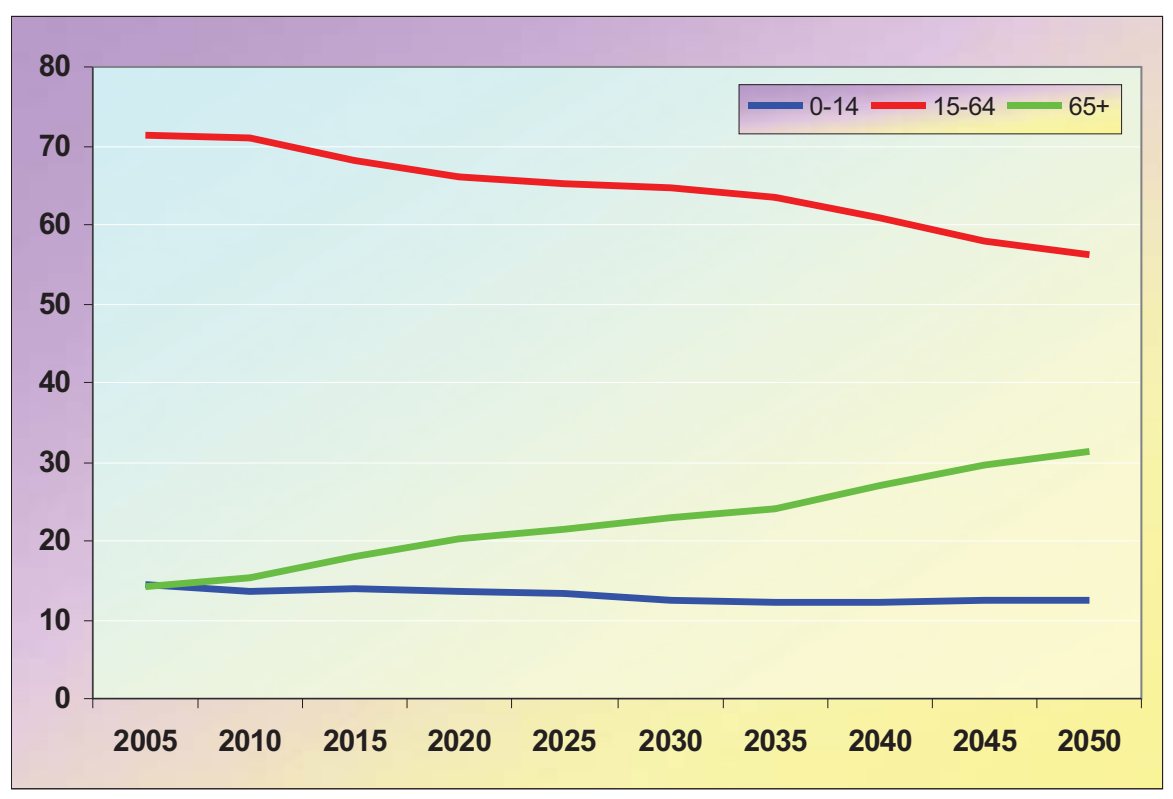

Zdroj: http://www.czso.cz

Počet lidí pracujících na jednoho důchodce se neustále snižuje. Dnes tato hodnota dosahuje čísla 5,03 pracujících osob na 1 důchodce. V roce 2050 to bude pouze 1,8 pracujících osob na 1 důchodce. Tato situace odráží celkový problém současné populace, růst počtu osob v důchodovém věku.

\subsection{Důvody nutnosti reformy}

Důvodů proč provést důchodovou reformu je celá řada, v následujícím výčtu jsou uvedeny pouze některé $\mathrm{z}$ nich. Je to zejména růst mandatorních výdajů, tzn. povinných 
výdajů SR (v roce 2005 tvořili 51,2 \% z celkových státních výdajů), největší podíl mandatorních výdajů tvoří sociální transfery domácnostem $(79,3 \%)$, jejich nejvyšší položkou jsou výdaje na důchody. Dalším důvodem je růst státního dluhu - v roce 2006 každý občan České republiky dlužil 78000 Kč. A konečně třetím důvodem je stárnutí obyvatelstva, který zahrnuje růst podílu důchodců ku ekonomicky aktivnímu obyvatelstvu, pokles ekonomicky aktivních obyvatel, delší důchodové období vlivem zkvalitňující se zdravotní péčí (růst nákladů na jedince), zvyšující se průměrný věk mužů a žen, pokles porodnosti a zvyšování věku prvorodiček.

\section{Penzijní reforma na Slovensku}

\subsection{Výchozí podmínky pro reformu a jejich podobnost s ČR}

Slovensko je př́kladem země s velmi podobnými výchozí podmínkami pro reformu penzijního systému a pro ekonomické reformy všeobecně jako ČR. Stejně jako Česká republika, tak i Slovensko bylo v 90. letech plně zaměstnáno ekonomickou transformací z centrálně plánované ekonomiky na ekonomiku tržní, velmi podobné jsou i historická dědictví obou států a předurčenost systému. Důchodový systém, který na Slovensku existoval do roku 2004, zohledňoval při výpočtu důchodu pouze pět nejlépe placených let z posledních deseti let před důchodem, výše důchodu byla shora ohraničena částkou cca 9200 Sk. Jednalo se o jednopilíŕový PAYG systém. Vedle něj existovaly, obdobně jako u nás, různé formy dobrovolného důchodového zabezpečení. Kromě penzijních fondů se jednalo o životní pojištění, kolektivní investování, apod.

Povinný, a proto dominantní byl však pouze dávkově definovaný systém. Financován byl průběžně prostřednictvím veřejnoprávní Sociální pojiš ovny, resp. jejího Základního fondu důchodového zabezpečení. Plynulo do něj, podobně jako je tomu v ČR, 28 procent mezd. Zaměstnanec přitom platil na důchodové pojištění 6,4 procenta a zaměstnavatel 21,6 procenta. Osoba samostatně výdělečně činná a spolupracující osoba pak z vyměřovacího základu odváděla celých 28 procent. ${ }^{3}$ Východiska pro reformu na Slovensku byla tedy velmi podobná jako východiska pro ČR. Výhody a nevýhody stávajícího systému byly přirozeně též velmi podobné. Základním důvodem pro provedení penzijní reformy v SR byly stejně jako v ČR zejména neudržitelnost průběžného dávkově definovaného systému $\mathrm{v}$ dlouhodobém horizontu $\mathrm{z}$ důvodu demografických změn v populaci a tím pádem hrozící vysoké deficity veřejných financí.

\subsection{Realizace reformy}

Slovenská reforma důchodového systému byla fakticky zahájena již prvního ledna 2004, kdy nabyl účinnosti nový Zákon o sociálním pojištění. Přesně za rok potom vstoupily v účinnost zákony o starobním důchodovém spoření a doplňkovém spoření a vytvořily tak právní rámec nového důchodového systému SR. Reforma tak vstoupila v platnost $\mathrm{k}$ 1.1.2005.

\subsection{Tři pilíře důchodového systému}

Slovensko se nechalo inspirovat doporučením Světové banky a zavedlo systém tří pilírư financování důchodů. Průběžně financovaný dávkově definovaný první pilíř byl dosud pilířem jediným. Představuje ho již zmiňovaná Sociální pojiš ovna, do které odvádí zaměstnavatel za pracovníky odvody ze mzdy. Do prvního pilíře je odváděno $10 \%$ ze

3 http://www.penize.cz/zpravy/1828/tygr-zarval-od-tater/ 
mzdy. Druhý, prríspěvkově definovaný pilíř je založen na spoření na osobních kapitálových účtech, kam se odvádí dalších $10 \%$ mzdy. Tento pilíŕ zastupují soukromé důchodové správcovské společnosti, jsou však pod př́ísným dohledem státu, který plně garantuje veškeré vložené prostředky do tohoto pilíře. Tento pilír funguje na principu podílových fondů, je zde možnost investovat do fondu růstového, vyváženého a konzervativního, které mají zajistit právě kapitálovou složku důchodového systému. V růstovém fondu může být až 80 \% akcií, je tedy nejrizikovější, ale může být i nejvýnosnější. Za dobu 24 měsíců existence fondu nesmí být průměrný výnos nižší než $50 \%$ průměrného výnosu konkurenčních růstových fondů. Do tohoto fondu může investovat občan, kterému chybí do důchodu více než 15 let, poté musí přejít na jiný. Vyvážený fond může tvořit až $50 \%$ akcií, ale minimálně 50 \% musí tvořit dluhopisy nebo vklady v bankách. Průměrný výnos fondu za 24 měsíců musí dosahovat alespoň $70 \%$ průměrného výnosu konkurence. Do tohoto fondu může investovat občan, kterému do důchodu chybí více než 7 let, poté musí přejít na fond konzervativní. Konzervativní fond musí $100 \%$ tvořit dluhopisy a vklady v bankách, průměrný výnos za 24 měsíců pak musí tvořit alespoň $90 \%$ průměrného výnosu konkurenčních fondů. Co se týče povinných přechodů mezi jednotlivými fondy, uvažuje se o změně z pevného data ( 7 a 15 let) na širší období, ale tyto úvahy zatím nebyly v parlamentu projednávány. ${ }^{4}$ Třetí, dobrovolný pilír představují doplňkové důchodové společnosti. Odvody do tohoto pilíře jsou zcela dobrovolné, ale zabezpečování ve třetím pilírí stát daňově zvýhodňuje. Je určen pro ty, kteří si chtějí přilepšit v penzi a rozhodnou se spořit u doplňkových důchodcovských společností. Stát motivuje ke spoření daňovými úlevami, kdy je možné si snížit základ daně ročně o 12.000 korun, ale je potřeba splnit podmínku spoření minimálně 10 let a dovršení 55 let při výplatě prostředků.

Tab. č. 1: Nový důchodový systém SR

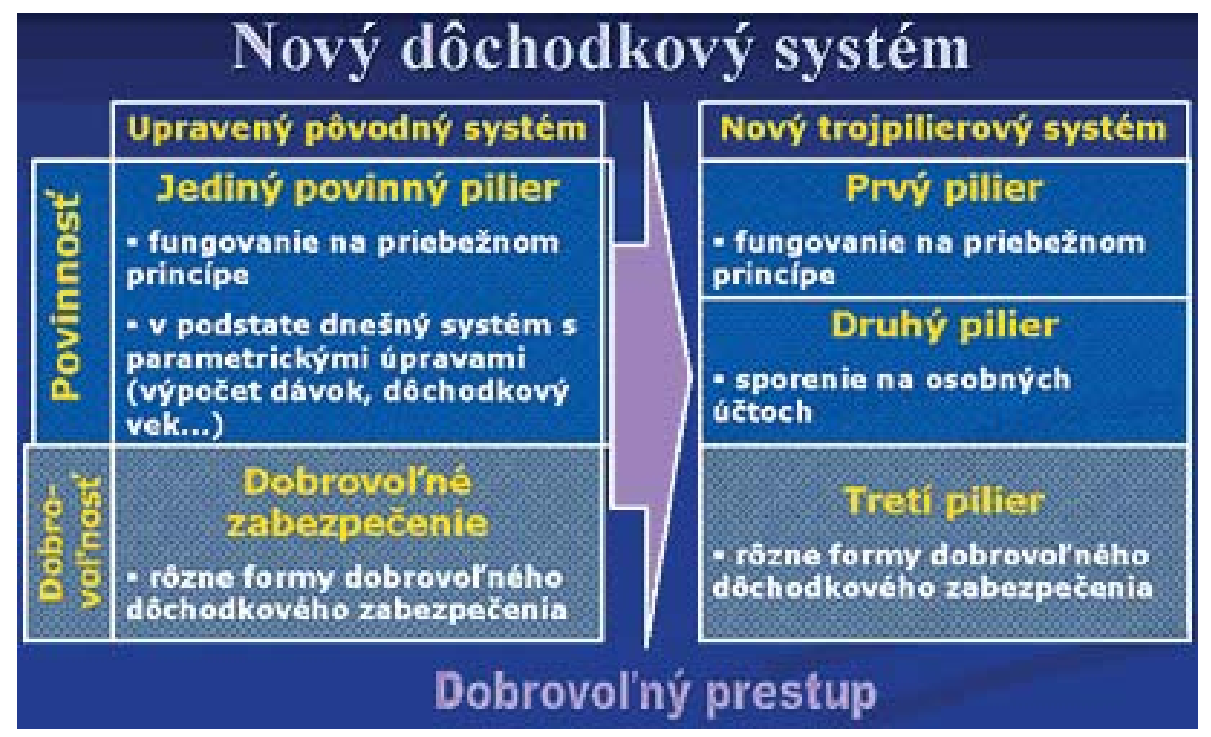

Zdroj: Eurofórum - prezentace MPSVR SR

\subsection{Přechod mezi systémy}

Jedním z nejvýznamnějších kroků slovenské reformy je zrušení dosavadní možnosti odchodu do předčasného důchodu a jeho nahrazením jakousi bonifikací: za každý měsíc, o který půjde penzista na odpočinek dříve, mu bude trvale snížen důchod o $0,5 \%$. A naopak, pokud půjde později, bude mu důchod o 0,5 \% zvýšen. Přechodné období mezi oběma systémy je potom upraveno rozdělením obyvatelstva do několika skupin.

4 http://www.mesec.cz/clanky/duchodova-reforma-na-slovensku-inspirace-pro-cr/ 
S přechodem na nový systém se též pojí problém financování. Roční výše deficitu byla odhadována na 10 - 18 mld. Sk. Částka 18 mld. se později ukázala jako odhad reálnější. Schodek penzijního systému měl být dle plánů financován z výnosů z privatizace, které činily 65 mld. Sk. Ty měly vystačit na krytí schodků do roku 2009. Pokud by se k nim přidalo dalších 50 mld. Sk, měla by Slovenská republika vystaráno do roku 2025. Dalším předpokládaným př́ijmem byl přebytek průběžného systému, jak ho budou občané opouštět. Deficit se pak předpokládal právě z titulu převodu na tř́ípilírový systém.

\section{Další penzijní systémy v zahraničí}

Nejen Česká a Slovenská republika je nucena řešit důchodový systém. Zaměřili jsme se proto i na některé další systémy fungující v zahraničí a na některé reformy důchodového systému. Snažili jsme se zjistit, zda je některý systém, resp. reforma uplatnitelná v České republice. Došli jsme k závěru, že takový systém v zahraničí neexistuje, protože každá země má svůj důchodový systém specificky nastavený a nelze ho tedy dost dobře přenášet.

\subsection{Penzijní reforma Chile}

V Chile se odhodlali k radikální penzijní reformě. Reformu provedl chilský liberální ekonom José Pińera. Systém průběžný se nacházel na pokraji zhroucení a byl nahrazen systémem plně kapitálovým. Hlavními důvody pro reformu bylo zvyšování doby dožití a změna demografického vývoje. Zatímco v roce 1960 přispívalo do starého penzijního systému na každého důchodce 10,8 ekonomicky aktivních obyvatel, tak v roce 1980 to byli už jen 2,2. Reforma výrazně podpořila ekonomiku. Systém založený na soukromém spoření rozhýbal chilský kapitálový trh. Došlo k poklesu míry chudoby z 45 \% v roce 1987 na $18,8 \%$ v roce 2003 , růst HDP v 80 . letech dosahoval v průměru $7 \%$ ročně a inflace se snížila z 27 \% v roce 1990 na 3,7\% v roce 2005.

\subsection{Penzijní reforma v Polsku}

Původní penzijní systém v Polsku byl dávkově definovaný. Sazba pojistného činila 45 \% hrubé mzdy a platil ji celou zaměstnavatel. Stal se finančně neudržitelným především kvůli nepř́iznivé demografické situaci Polska. Reforma byla spuštěna v roce 1999. Původní PAYG systém se reformoval v třípilírový systém. Polská populace byla rozdělena do tří skupin. Lidé narození do roku 1948, narození mezi lety 1949 až 1968 a narozeni v roce 1969 a mladší. Rozdíl mezi nimi spočívá v tom, že skupina narozená v roce 1969 a později se musí povinně účastnit druhého pilíře a skupina narozená mezi lety 1949 až 1968 se mohla účastnit druhého pilíře dobrovolně.

\section{3 Švédská penzijní reforma}

Do počátku 90. let existoval ve Švédsku průběžně definovaný př́íspěvkový systém PAYG, který zahrnoval jednotné dávky s relativně výnosovým systémem (označovaný ATP). Stejně jako všechny systémy založené na PAYG, ani tento však nebyl finančně udržitelný. Vyžadoval 30 let krytí pro plnou výplatu penzijních dávek a dávky samotné se vypočítávaly z průměru nejlepších účastníkových 15 let výdělku. Reforma byla založena na nahrazení dosavadního dávkové definovaného systému PAYG vytvořením kombinace dvou př́íspěvkově definovaných systémů NDC a FDC. Vedle těchto dvou systémů existuje též záruka pro celoživotně chudé ve formě tzv. zaručeného důchodu. ${ }^{5}$

5 DP - Důchodová reforma v České republice se zaměřením na doplňkový systém. Eva Přikrylová. 2005 


\subsection{Penzijní systém USA}

Odhady ve Spojených státech ukazují, že za současné legislativní úpravy by se mohly výdaje systému sociálního zabezpečení na důchodové dávky a na zdravotní péči pro staré občany zvýšit ze současných $10 \%$ HDP na $18 \%$ v roce 2030 a budou stoupat i potom. K pokrytí těchto $18 \%$ HDP ze zvýšení daní by bylo třeba zdvojnásobit osobní daň z př́ijmu nebo zvýšit odvody z mezd a platů z $15 \%$ na více než $35 \%{ }^{6}{ }^{6}$

Základem důchodového systému USA je průběžně financovaný systém, který tvoří zhruba $40 \%$ penzijního systému, což pro penzisty znamená př́ijem pouze $32 \% \mathrm{z}$ průměrné mzdy. Odvody $\mathrm{z}$ mezd tvoří $12,4 \%$ mzdy (polovina zaměstnanec, polovina zaměstnavatel). Suma těchto odvodů je v současné době asi o 20 \% vyšší než státní výdaje na dávky sociálního zabezpečení. Tento přebytek by měl vydržet do roku 2015 a zatím je využíván na snížení deficitu federálního rozpočtu. Udržování výše dávek stanovených současnými zákony by si vyžádalo zvýšení sazby odvodů z mezd z $12 \%$ na $16 \%$ a poté jejich další postupné zvyšování až na $19 \%$ po roce 2030.

Kromě průběžného systému existuje v USA systém zaměstnaneckých důchodových plánů, převážně příspěvkově definovaných. Další možností, jak si zvýšit budoucí prŕijem je soukromé spoření na důchod.

\subsection{Riesterova německá reforma}

V roce 2001 byl v Německu schválen nový reformní penzijní zákon, a protože ho prosadil ministr práce a sociálních věcí Walter Riester, nazývá se reforma Riesterova. Jedním z hlavních změn je zavedení státní podpory pro podpůrný penzijní systém spoření. V tomto je možno pojmout reformu jako první krok na cestě v přeměně systému PAYG na systém vícefondový.

\subsubsection{Cíle Riesterovy reformy}

Cílem Riesterovy reformy je zamezit stoupajícím nemzdovým nákladům na pracovní sílu (tzn. růstu povinných odvodů zaměstnance a zaměstnavatele) a udržet př́spěvkovou míru do systému veřejného důchodového pojištění pod hranicí $20 \%$ do roku 2020 a pod hranicí $22 \%$ do roku 2030.

Penze budou postupně sníženy z běžné úrovně $70 \%$ průměrného čistého výdělku na hladinu okolo $67 \%$ - $68 \%$ do roku 2030. Omezený růst státních penzí bude postupně nahrazen zvýšením míry příspěvků pocházejících ze zaměstnaneckých nebo soukromých penzí. Tyto budou zpočátku podporovány státem. S použitím vládního scénáře ekonomického a demografického vývoje budou v Německu v roce 2030 státní důchody tvořit $63,3 \%$ hrubé průměrné mzdy zaměstnance, v roce 2050 pak $63 \%$, zatímco nyní představují $70 \%$. ${ }^{7}$

\subsection{Velká Británie}

Velká Británie má nejnižší podíl státních důchodů v EU. Státní systém se skládá ze dvou složek. První složkou jsou plošné dávky a druhou dávky odvozené od výše výdělků. Dávky se vyplácejí pouze zaměstnancům, nikoliv osobám samostatně výdělečně činným. Státní penze dosahuje přibližně $20 \%$ mzdy. Vzhledem k této nízké státní penzi má $96 \%$ občanů uzavřeno penzijní pojištění ve fondech. Podle zákona jsou zaměstnavatelé povinni přispívat do fondu za své zaměstnance, pokud přispívají zaměstnanci. Průměrná penze ve

6 http://www.obcinst.cz/clanek.asp?id=672

7 www.valencik.cz/marathon/04/mar040403.htm 
Velké Británii dosahuje při kumulaci státní penze a penze z fondu okolo $65 \%$ mzdy před odchodem do penze.

\section{Kritéria pro hodnocení variant}

Přestože jsme $v$ týmu jednotní a jsme zaměřeni spíše ekonomicky, máme ekonomických kritérií méně než sociálních. Toto jsme si vysvětlili tím, že systém je založen hlavně na myšlence solidarity a ze sociálního hlediska je v něm zahrnuto více aspektů, které je třeba zohlednit.

\subsection{Ekonomická}

Mezi ekonomická kritéria jsme zařadili výši odvodů do státního pilíře, výši odvodů na individuální účty, náhradový poměr (výši důchodu vzhledem ke mzdě) a podíl výdajů na důchody $\mathrm{k}$ HDP.

\subsection{Politická}

Jako nejdůležitější politická kritéria vnímáme administrativní náročnost, transparentnost, možnost vyvázání ze státního pilíře a systém se stejnými možnostmi pro všechny.

\subsection{Sociální}

Mezi kritéria sociální řadíme závislost na státu, garanci minimálního důchodu, zda zaměstnavatel platí na zaměstnance, nebo státu, podporu druhého a třetího pilíre státem, vyjmutí invalidních a sirotčích dávek z penzijního systému, věk odchodu do důchodu, míru závislosti osob v důchodovém věku na přispěvatelích do systému, možnost předčasného důchodu, odměnu za pozdější odchod do důchodu, zda spořím na sebe, nebo na jiné, diskriminaci a závislost výše důchodu na počtu dětí.

\subsection{Přechodová}

Jako kritéria přechodová jsme určili nekrácení důchodu současných důchodců, možnost volby piliřru, zda ano či ne, možnost volby systému - nový vs. starý a časový horizont pro zavedení.

\section{Varianty důchodové reformy}

Návrhy variant důchodového systému vycházejí z návrhů politických stran. Zvolili jsme tak proto, že o těchto systémech lze sehnat relativně více informací a bude proto snazší vybrat „ideální“ systém. Do variant jsme zahrnuli také současný systém. Přestože víme, že je nutná reforma, zajímalo nás, jak si v našem hodnocení obstojí. Přidali jsme také variantu společnosti ING, které říkáme třešnička na dortu. Na důchodový systém pohlíží z demografického hlediska a opět jsme byli zvědaví, jak obstojí podle našich kritérií.

8 http://www.mesec.cz/clanky/duchody-v-evropske-unii/ 


\subsection{Současný systém (viz výše)}

\section{2 ČSSD}

Tato varianta navrhuje přechod na systém pomyslných individuálních účtů (NDC), nadále průběžný způsob financování (PAYG), systém pomyslných individuálních účtů, důchod z toho, co každý na svůj „,virtuální“ účet vložil (každý má přehled o svých odvodech). Důchod má být vyplácen ve formě doživotní anuity zohledňován valorizací, použití unisex úmrtnostní tabulky, garance minimálního důchodu je ve výši 1,2 násobku životního minima do roku 2040, poté snížení na 1,1 násobek životního minima. Životní minimum bude valorizováno dle inflace a tř́ čtvrtin tempa růstu průměrné reálné mzdy, nedosahuje-li penze životního minima, stát ji dorovnává. Poslední možnost odejít do důchodu dle starého systému je pro tuto variantu v roce 2009 , poté postupně klesá váha PAYG DB a roste váha NDC. Zahrnuje postupné zvyšování věku odchodu do důchodu až na 65 let pro muže i ženy, navrhovaná pojistná sazba je do roku 2010 systém NDC $21 \%$, celková pojistná sazba $28 \%$, od roku 2010 potom systém NDC 22,6\%, celková pojistná sazba 29,6\% (převod pojistného na státní politiku zaměstnanosti na individuální účty).

Výhodami systému jsou omezení nadměrného přerozdělování směrem $\mathrm{k}$ občanům s nízkými příjmy, přímá vazba mezi výší odvodů a výší důchodu, růst osobní zodpovědnosti, finančně vyrovnaný systém a transparentnost systému, každý ví, kolik si naspořil. Mezi nevýhody řadíme vyšší administrativní náročnost, pokles výše důchodu u žen (kratší doba pojištění a nižší mzda), pouhé přenastavení parametrů systému, reálně peníze stejně nebudou (stále systém průběžného financování). Základní dopady systému jsou pokles výdajů penzijního systému ve vztahu k HDP, motivace žen k pozdějšímu odchodu do důchodu, pokles náhradového poměru, $60 \%$ nově příchozích důchodců pod úrovní hranice chudoby (25\%), výhodnost spíše pro lidi s vyššími př́ijmy.

\subsection{KDU-ČSL}

Varianta KDU - ČSL navrhuje dvoupilířový systém obsahující státní a fondový pilír. Systém je založen na vícezdrojové financování, dobrovolném vázání, možnosti dobrovolného částečného vyvázání ze státního penzijního systému spočívající v přsunu odvodů ze státního pilíře do soukromého systému zabezpečení. Možnost částečného vyvázání je podmíněna přidáním vlastních prostředků do soukromého systému zabezpečení a je nevratná. Navrhuje zvýšení věku odchodu do důchodu na 65 let při zachování redukce u žen podle počtu dětí. Navrhovaná pojistná sazba je $28 \% \mathrm{z}$ hrubé mzdy, z toho starobní důchody $20 \%$ a nestarobní důchody $8 \%$. Důchod z fondového pilíře bude vyplácen ve formě doživotní anuity, zohledňován valorizací, při použití úmrtnostní tabulky pro muže a ženy zvláš . Mezi výhody patří možnost vyvázání či řešení oblast výpadku prŕíjmů vyplývající ze snížení pojistné sazby, mezi nevýhody administrativní náročnost.

\subsection{ODS}

Tato varianta navrhuje dvoupilířový systém - státní a soukromý pilíř, zahrnuje kombinaci solidarity a osobní iniciativy. Rovný důchod pro všechny ve výši $20 \%$ průměrné mzdy bude vyplácen ze státního pilíre a bude mzdově valorizován. Navrhuje pokles povinných plateb na $20 \% \mathrm{z}$ hrubé mzdy (starobní důchody $12 \%$ ) a přesun takto získaných prostředků do soukromého pilíře a možnost odečtu od daňového základu u soukromého pilířre. Zahrnuje 3 stupně přechodu. Představuje zprůhlednění dnešního systému, převodem př́spěvku zaměstnavatele na sociální pojištění do hrubé mzdy zaměstnance, postupné zvyšování věku odchodu do důchodu na 65 let, poté dojde ke sjednocení věku pro muže 
i ženy a k postupnému růstu o 2 měsíce ročně až do výše 71 let pro obě pohlaví. Výhodami jsou pokles administrativních nákladů, snížení sociálního pojištění, větší důraz na individuální pojištění, zdánlivě nejefektivnější varianta, zvýšení zásluhovosti. Mezi nevýhody řadíme nedostatek financí, český kapitálový trh zatím není na tento systém připraven, nové vlády nesmí podlehnout pokušení zvýšit minimální mzdu (např. předvolební návrhy na získání voličů z řad důchodců), lidé moc nechtějí spořit dobrovolně.

\subsection{Bez dětí nejsou důchody}

Mnoho důchodců nemá děti, což tlačí na vznik nerovnováhy systému a neférovost. $\mathrm{V}$ této variantě jsou důchody rozlišeny podle toho, kdo má děti a kdo ne. Důvody pro menší počet dětí nejsou ekonomické, ale souvisejí spíše se změnou životního stylu, který si lidé zvolili sami. Problém penzí není politickou chybou, ale problémem lidí s „moderním“ životním stylem. Jedná se o třípilíŕový systém, zahrnující PAYG, fondový pilíŕ a dobrovolný pilír. Výhodami jsou dlouhodobé zajištění důchodů pro většinu obyvatel (povinná účast všech dle typu), relativní férovost systému, transparentnost a pokles citlivosti důchodů na demografické změny. Nevýhodný je v tom, že mají-li občané 1 nebo 2 děti, budou pobírat pouze krácený $\mathrm{PAYG}$ důchod, $\mathrm{v}$ krátkém období bude docházet $\mathrm{k}$ deficitům státu, $\mathrm{v}$ dlouhém se však vyrovnají, neřeší situaci, kdy lidé nemohou mít děti a otec je vždy neznámý.

\section{Aplikace metod vícekriteriálního hodnocení}

V prvním kroku jsme museli zjistit váhy jednotlivých kritérií. Pro stanovení vah kritérií jsme se rozhodli použít metodu postupného rozvrhu vah. Ta spočívá v několika krocích. Nejprve jsme jednotlivá kritéria seřadili do dílčích skupin podle př́ibuznosti jejich věcné náplně. $\mathrm{V}$ dalším kroku jsme pomocí Saatyho metody určily váhy jednotlivých skupin kritérií (Tab. 2). Tato metoda umožňuje nejen zjistit preferované vztahy mezi dvojicí kritérií, ale umožňuje vyjádřit i velikost této preference. V posledním kroku jsme též pomocí Saatyho metody stanovení vah určily váhy kritérií v jednotlivých skupinách (analogicky dle Tab. 3). Druhý krok spočíval ve zjištění dopadů jednotlivých variant na stanovená kritéria. Na základě zjištěných jsme pokračovali dále. Jelikož máme soubor kritérií kvalitativní i kvantitativní povahy, a prvně jmenovaných je většina, rozhodli jsme se pro stanovení užitku jednotlivých variant použít metodu váženého pořadí. V prvním kroku jsme určili pořadí variant vzhledem $\mathrm{k}$ jednotlivým kritériím. Vzhledem $\mathrm{k}$ tomu, že máme 5 variant, nejlepší varianta byla ohodnocena hodnotou 1 a nejhorší hodnotou 5 . Dále jsme provedli přepočet hodnot na užitky dílčích ohodnocení, kdy nejlepší varianta nabývá hodnoty 5 a nejhorší hodnoty 1 . V posledním kroku jsme pronásobili váhy jednotlivých kritérií s užitky variant a dostali jsem pořadí jednotlivých variant. Grafické znázornění našeho postupu jsme uvedli v tabulkách v př́loze.

Tab. č. 2:Saatyho metoda pro stanovení vah skupin kritérií

\begin{tabular}{||l|c|c|c|c|c|c||}
\hline \multicolumn{1}{|c|}{ Kritéria } & Ekonomická & Politická & Sociální & $\begin{array}{c}\text { Přechodová, } \\
\text { krátkodobá }\end{array}$ & $\begin{array}{c}\text { Geometrický } \\
\text { průměr }\end{array}$ & $\begin{array}{c}\text { Normovaná } \\
\text { váha }\end{array}$ \\
\hline Ekonomická & 1 & 2 & 1,5 & 2,5 & 1,65487546 & $38 \%$ \\
\hline Politická & 0,5 & 1 & 0,5 & 1,2 & 0,740082804 & $17 \%$ \\
\hline Sociální & 0,67 & 2,00 & 1,00 & 2 & 1,277886208 & $30 \%$ \\
\hline Přechodová & 0,40 & 0,83 & 0,50 & 1 & 0,638943104 & $15 \%$ \\
\hline SUMA & & & & & $\mathbf{4 , 3 1 1 7 8 7 5 7 7}$ & $\mathbf{1 0 0 \%}$ \\
\hline
\end{tabular}


Tab. č. 3: Saatyho metoda pro stanovení vah ekonomických kritérií

\begin{tabular}{|l|c|c|c|c|c|c|c||}
\hline \multicolumn{1}{|c|}{ Ekonomická kritéria } & K1 & $\mathbf{K 2}$ & $\mathbf{K 3}$ & $\mathbf{K 4}$ & $\begin{array}{c}\text { Geometrický } \\
\text { průměr }\end{array}$ & $\begin{array}{c}\text { Normovaná } \\
\text { váha }\end{array}$ & Celková váha \\
\hline \hline $\begin{array}{l}\text { K1 - Výše odvodů do státního } \\
\text { pilíře }\end{array}$ & 1,00 & 0,60 & 0,60 & 0,50 & 0,65 & 0,16 & $6 \%$ \\
\hline $\begin{array}{l}\text { K2 - Výše odvodů na individuální } \\
\text { účty }\end{array}$ & 1,67 & 1,00 & 0,90 & 0,80 & 1,05 & 0,25 & $10 \%$ \\
\hline K3 - Náhradový poměr & 1,67 & 1,11 & 1,00 & 1,00 & 1,17 & 0,28 & $11 \%$ \\
\hline $\begin{array}{l}\text { K4 - Podíl výdajů na důchody } \\
\text { k HDP }\end{array}$ & 2,00 & 1,25 & 1,00 & 1,00 & 1,26 & 0,31 & $12 \%$ \\
\hline SUMA & & & & & 4,12 & 1,00 & $38 \%$ \\
\hline
\end{tabular}

\section{Závěr}

Na základě předchozích výpočtů jsme došli k následujícímu pořadí variant: vítězem se stala varianta KDU-ČSL, další místa obsadila ODS, Bez dětí nejsou důchody, ČSSD a jako nejhorší se jeví náš současný důchodový systém. Zajímavé je poukázat na fakt, že celý náš tým, pokud bychom si měli vybrat jednu politickou stranu, je spíše prŕivržencem ODS, přesto zvítězila varianta KDU-ČSL. To snad alespoň trochu poukazuje na naši nestrannost, o kterou jme se při hodnocení variant maximálně snažili. Mile nás překvapilo, že při použití daných postupů a metod, byl současný neudržitelný systém ohodnocen jako nejhorší varianta. Je to další důkaz toho, že je reforma současného důchodového systému v ČR skutečně nutná.

Z hlediska hodnocení dle jednotlivých skupin kritérií je zajímavé, že vítězná varianta dopadla $\mathrm{v}$ hodnocení politických kritérií téměř nejhưr̆, stejně tak je zajímavé umístění současného systému třikrát na posledním místě. „Body“ získal tento systém pouze při hodnocení kritérií přechodových, a to zejména proto, že je tento systém již zavedený a nic se nemusí měnit. Váha této skupiny kritérií však nestačí na to, aby se tato varianta více prosadila. Z ekonomického hlediska se jako nejvýhodnější jeví varianta Bez dětí nejsou koláče, která výrazně snižuje roli státu v důchodovém systému. Umístění vítězné varianty na čtvrtém místě v rámci politických kritérií nám zase naznačuje, že nebude jednoduché tento systém politicky prosadit a zavést. Varianta KDU-ČSL by tedy musela být dobře komunikována a prosazována.

Při použití uvedených metod a postupů se nám tedy podařilo splnit cíl této seminární práce, tj. nejen podat obraz o existujících důchodových systémech a provedených reformách v zahraničí a popsat fungování a problémy současného systému v ČR, ale též vybrat vhodnou variantu reformy důchodového systému pro Českou republiku.

\section{Použité zdroje}

[1] FOTR, J. a kol.: Manažerské rozhodování. Postupy, metody, nástroje. Praha: Ekopress 2006. ISBN 80-86929-15-9.

[2] DP - Famfulová, Eva: Di̊chodový systém ČR a možnosti jeho reformy. Praha: VŠE 2002. DP6295HP

[3] DP - Korandová, Petra: Penzijní systémy s povinným fondovým pilírem. Praha: VŠE 2005. DP 8205 HP 
[4] DP - Minářová, Lenka: Di̊chodové zabezpečení v České republice. Praha: VŠE 2007.

[5] DP - Němec, Jan: Dưchodový systém ČR a možnosti jeho reformování. Praha: VŠE 2005. DP 9143 FI

[6] DP - Přrikrylová, Eva: Di̊chodová reforma v České republice se zaměřením na doplňkový systém. Praha: VŠE 2005.

[7] DP - Šubrt Pavel: Reforma diochodového systému v České republice. Praha: VŠE 2005.

[8] Analýza názorů občanů na pokračování důchodové reformy: http://www.mpsv.cz/files/clanky/3406/analyza_nazory_na_DR_151206.pdf

[9] http://www.cssz.cz

[10] http://www.czso.cz/csu/redakce.nsf/i/obyvatelstvo_(demografie)_lide

[11] http://www.demografie.info

[12] http://www.finance.cz/duchody-a-penze/informace/duchodovy-system/prispevkove-a-davkove-definovane-systemy/

[13] http://www.finance.cz/duchody-a-penze/informace/duchodovy-system/zpusoby-financovani/

[14] http://www.mesec.cz/clanky/evropska-unie-nema-na-duchody/

[15] http://www.mesec.cz/clanky/duchodova-reforma-na-slovensku-inspirace-pro-cr/

[16] http://www.mesec.cz/clanky/duchody-u-nas-a-v-evrope/

[17] http://www.mesec.cz/clanky/duchody-v-evropske-unii/

[18] http://www.mesec.cz/clanky/penzijni-reforma-soucasny-stav/

[19] http://www.mpsv.cz/files/clanky/2235/zaverecna_zprava.pdf

[20] http://www.mpsv.cz/files/clanky/2765/06_05_05PopisING.pdf

[21] http://www.mpsv.cz/files/clanky/2277/Popis_varianty_CSSD_NDC.pdf

[22] http://www.mpsv.cz/files/clanky/2278/Popis_KDU-CSL.pdf

[23] http://www.mpsv.cz/files/clanky/2280/Popis_varianty_ODS_RD.pdf

[24] http://www.obcinst.cz/clanek.asp?id=672

[25] http://www.penize.cz/info/zpravy/reforma.asp

[26] http://www.penize.cz/info/zpravy/zprava.asp?IDP=1\&NewsID=3147

[27] http://www.penize.cz/info/zpravy/zprava.asp?IDP=1\&NewsID=3159

[28] http://www.penize.cz/info/zpravy/zprava.asp?IDP=1\&NewsID=3176

[29] http://www.penize.cz/info/zpravy/zprava.asp?IDP=1\&NewsID=3556

[30] http://www.sfinance.cz/page.php?page_id=3208

[31] http://www.valencik.cz/marathon/04/mar040403.htm

[32] http://www.mesec.cz/clanky/cesko-slovensko-boj-o-stastne-stari/

[33] http://www.penize.cz/zpravy/1828/tygr-zarval-od-tater/ 


\section{Př́lohy}

Tab. č. 4: Tabulka pořadí variant dle jednotlivých kritérií

\begin{tabular}{|c|c|c|c|c|c|}
\hline Kritéria/Modely & $\begin{array}{l}\text { Současný } \\
\text { systém }\end{array}$ & ČSSD & KDU-ČSL & ODS & \begin{tabular}{|c|}
$\begin{array}{c}\text { Bez dětí nejsou } \\
\text { důchody }\end{array}$ \\
\end{tabular} \\
\hline \multicolumn{6}{|l|}{ Ekonomické } \\
\hline K1 - Výše odvodů do státního pilíře & 4,5 & 2,5 & 1 & 2,5 & 4,5 \\
\hline K2 - Výše odvodů na individuální účty & 4,5 & 3 & 2 & 4,5 & 1 \\
\hline K3 - Náhradový poměr & 3 & 4,5 & 1,5 & 4,5 & 1,5 \\
\hline K4 - Podíl výdajů na důchody k HDP & 5 & 2 & 4 & 1 & 3 \\
\hline \multicolumn{6}{|l|}{ Politické } \\
\hline K5 - Administrativní náročnost & 4,5 & 3 & 4,5 & 1,5 & 1,5 \\
\hline K6 - Transparentnost & 4,5 & 2,5 & 4,5 & 2,5 & 1 \\
\hline K7 - Možnost vyvázání ze státního pilíře & 3,5 & 3,5 & 1 & 3,5 & 3,5 \\
\hline K8 - Systém se stejnými možnostmi pro všechny & 3,5 & 1,5 & 3,5 & 1,5 & 5 \\
\hline \multicolumn{6}{|l|}{ Sociální } \\
\hline K9 - Závislost na státu & 5 & 3 & 1,5 & 1,5 & 4 \\
\hline K10 - Garance minimálního důchodu & 2 & 2 & 2 & 4 & 5 \\
\hline K11 - Zaměstnavatel platí na zaměstnance, nebo státu & 3,5 & 3,5 & 3,5 & 1 & 3,5 \\
\hline K12 - Podpora druhého a třetího pilíře státem & 2,5 & 2,5 & 2,5 & 2,5 & 5 \\
\hline $\begin{array}{l}\text { K13 - Vyjmutí invalidních, vdovských } \\
\text { a sirotčích dávek z penzijního systému }\end{array}$ & 4 & 4 & 4 & 1,5 & 1,5 \\
\hline K14 - Věk odchodu do důchodu & 4 & 2 & 2 & 5 & 2 \\
\hline $\begin{array}{l}\text { K15 - Míra závislosti osob v důchodovém věku } \\
\text { na přispěvatelích do systému }\end{array}$ & 4,5 & 3 & 1 & 2 & 4,5 \\
\hline K16 - Možnost předčasného důchodu & 4 & 4 & 1,5 & 1,5 & 4 \\
\hline K17 - Odměna pro pozdější odchod do důchodu & 1,5 & 4 & 1,5 & 4 & 4 \\
\hline K18 - Spořím na sebe, nebo na jiné & 5 & 2 & 3,5 & 3,5 & 1 \\
\hline K19-Diskriminace & 1,5 & 4 & 1,5 & 4 & 4 \\
\hline K20 - Závislost výše důchodu na počtu dětí & 3,5 & 3,5 & 3,5 & 3,5 & 1 \\
\hline \multicolumn{6}{|l|}{ Přechodové, tedy krátkodobé } \\
\hline K21 - Nekrácení důchodu současných důchodců & 2,5 & 2,5 & 2,5 & 2,5 & 5 \\
\hline K22 - Možnost volby pilířo̊, zda ano či ne & 2 & 4 & 1 & 4 & 4 \\
\hline K23 - Možnost volby systému - nový vs. starý & 4 & 4 & 1,5 & 1,5 & 4 \\
\hline K24 - Časový horizont pro zavedení & 1 & 4 & 2 & 3 & 5 \\
\hline
\end{tabular}


Tab. č. 5: Dílčí ohodnocení variant dle jednotlivých kritérií a vícekriteriální funkce utility

\begin{tabular}{|c|c|c|c|c|c|c|}
\hline Kritéria/Modely & Váhy & $\begin{array}{c}\text { Současný } \\
\text { systém }\end{array}$ & ČSSD & KDU-ČSL & ODS & $\begin{array}{c}\text { Bez dětí nejsou } \\
\text { důchody }\end{array}$ \\
\hline \multicolumn{7}{|l|}{ Ekonomické } \\
\hline K1 - Výše odvodů do státního pilíře & $6 \%$ & 1,5 & 3,5 & 5 & 3,5 & 1,5 \\
\hline K2 - Výše odvodů na individuální účty & $10 \%$ & 1,5 & 3 & 4 & 1,5 & 5 \\
\hline K3 - Náhradový poměr & $11 \%$ & 3 & 1,5 & 4,5 & 1,5 & 4,5 \\
\hline K4 - Podíl výdajů na důchody k HDP & $12 \%$ & 1 & 4 & 2 & 5 & 3 \\
\hline \multicolumn{7}{|l|}{ Politické } \\
\hline K5 - Administrativní náročnost & $3 \%$ & 1,5 & 3 & 1,5 & 4,5 & 4,5 \\
\hline K6 - Transparentnost & $6 \%$ & 1,5 & 3,5 & 1,5 & 3,5 & 5 \\
\hline K7 - Možnost vyvázání ze státního pilíře & $5 \%$ & 2,5 & 2,5 & 5 & 2,5 & 2,5 \\
\hline $\begin{array}{l}\text { K8 - Systém se stejnými možnostmi } \\
\text { pro všechny }\end{array}$ & $4 \%$ & 2,5 & 4,5 & 2,5 & 4,5 & 1 \\
\hline \multicolumn{7}{|l|}{ Sociální } \\
\hline K9 - Závislost na státu & $2 \%$ & 1 & 3 & 4,5 & 4,5 & 2 \\
\hline K10 - Garance minimálního důchodu & $3 \%$ & 4 & 4 & 4 & 2 & 1 \\
\hline $\begin{array}{l}\text { K11 - Zaměstnavatel platí na zaměstnance, } \\
\text { nebo státu }\end{array}$ & $2 \%$ & 2,5 & 2,5 & 2,5 & 5 & 2,5 \\
\hline K12 - Podpora druhého a třetího pilíře státem & $2 \%$ & 3,5 & 3,5 & 3,5 & 3,5 & 1 \\
\hline $\begin{array}{l}\text { K13 - Vyjmutí invalidních, vdovských } \\
\text { a sirotčích dávek z penzijního systému }\end{array}$ & $1 \%$ & 2 & 2 & 2 & 4,5 & 4,5 \\
\hline K14 - Věk odchodu do důchodu & $3 \%$ & 2 & 4 & 4 & 1 & 4 \\
\hline $\begin{array}{c}\text { K15 - Míra závislosti osob v důchodovém } \\
\text { věku na přispěvatelích do systému }\end{array}$ & $3 \%$ & 1,5 & 3 & 5 & 4 & 1,5 \\
\hline K16 - Možnost předčasného důchodu & $3 \%$ & 2 & 2 & 4,5 & 4,5 & 2 \\
\hline $\begin{array}{l}\text { K17 - Odměna pro pozdější odchod } \\
\text { do důchodu }\end{array}$ & $2 \%$ & 4,5 & 2 & 4,5 & 2 & 2 \\
\hline K18 - Spořím na sebe, nebo na jiné & $3 \%$ & 1 & 4 & 2,5 & 2,5 & 5 \\
\hline K19 - Diskriminace & $3 \%$ & 4,5 & 2 & 4,5 & 2 & 2 \\
\hline K20 - Závislost výše důchodu na počtu dětí & $2 \%$ & 2,5 & 2,5 & 2,5 & 2,5 & 5 \\
\hline \multicolumn{7}{|l|}{ Přechodové, tedy krátkodobé } \\
\hline $\begin{array}{l}\text { K21 - Nekrácení důchodu současných } \\
\text { důchodců }\end{array}$ & $4 \%$ & 3,5 & 3,5 & 3,5 & 3,5 & 1 \\
\hline K22 - Možnost volby pilířů, zda ano či ne & $3 \%$ & 4 & 2 & 5 & 2 & 2 \\
\hline $\begin{array}{l}\text { K23 - Možnost volby systému - nový vs. } \\
\text { starý }\end{array}$ & $3 \%$ & 2 & 2 & 4,5 & 4,5 & 2 \\
\hline K24 - Časový horizont pro zavedení & $4 \%$ & 5 & 2 & 4 & 3 & 1 \\
\hline SUMA & $100 \%$ & 2,35018 & 2,941 & 3,634215 & 3,079 & 2,991517 \\
\hline POŘADÍ & & 5 & 4 & 1 & 2 & 3 \\
\hline
\end{tabular}


Tab. č. 6: Dílčí ohodnocení variant dle ekonomických kritérií a vícekriteriální funkce utility

\begin{tabular}{|c|c|c|c|c|c|c|}
\hline Kritéria/Modely & Váhy & $\begin{array}{c}\text { Současný } \\
\text { systém }\end{array}$ & ČSSD & KDU-ČSL & ODS & $\begin{array}{c}\text { Bez dětí nejsou } \\
\text { důchody }\end{array}$ \\
\hline \multicolumn{7}{|l|}{ Ekonomické } \\
\hline K1 - Výše odvodů do státního pilíře & $6 \%$ & 1,5 & 3,5 & 5 & 3,5 & 1,5 \\
\hline K2 - Výše odvodů na individuální účty & $10 \%$ & 1,5 & 3 & 4 & 1,5 & 5 \\
\hline K3 - Náhradový poměr & $11 \%$ & 3 & 1,5 & 4,5 & 1,5 & 4,5 \\
\hline \multirow[t]{3}{*}{ K4 - Podíl výdajů na důchody k HDP } & $12 \%$ & 1 & 4 & 2 & 5 & 3 \\
\hline & & 0,6793791 & 1,13549 & 1,413207 & 1,1072 & 1,41819 \\
\hline & & 5 & 3 & 2 & 4 & 1 \\
\hline
\end{tabular}

Tab. č. 7: Dílčí ohodnocení variant dle politických kritérií a vícekriteriální funkce utility

\begin{tabular}{|c|c|c|c|c|c|c|}
\hline Kritéria/Modely & Váhy & $\begin{array}{c}\begin{array}{c}\text { Současný } \\
\text { systém }\end{array} \\
\end{array}$ & ČSSD & KDU-ČSL & ODS & $\begin{array}{c}\text { Bez dětí nejsou } \\
\text { důchody }\end{array}$ \\
\hline \multicolumn{7}{|l|}{ Politické } \\
\hline K5 - Administrativní náročnost & $3 \%$ & 1,5 & 3 & 1,5 & 4,5 & 4,5 \\
\hline K6 - Transparentnost & $6 \%$ & 1,5 & 3,5 & 1,5 & 3,5 & 5 \\
\hline K7 - Možnost vyvázání ze státního pilíře & $5 \%$ & 2,5 & 2,5 & 5 & 2,5 & 2,5 \\
\hline \multirow[t]{3}{*}{$\begin{array}{l}\text { K8 - Systém se stejnými možnostmi } \\
\text { pro všechny }\end{array}$} & $4 \%$ & 2,5 & 4,5 & 2,5 & 4,5 & 1 \\
\hline & & 0,3476649 & 0,57356 & 0,478106 & 0,6127 & 0,56263 \\
\hline & & 5 & 2 & 4 & 1 & 3 \\
\hline
\end{tabular}

Tab. č. 8: Dílčí ohodnocení variant dle sociálních kritérií a vícekriteriální funkce utility

\begin{tabular}{|c|c|c|c|c|c|c|}
\hline Kritéria/Modely & Váhy & $\begin{array}{l}\text { Současný } \\
\text { systém }\end{array}$ & ČSSD & KDU-ČSL & ODS & \begin{tabular}{|c|}
$\begin{array}{c}\text { Bez dětí nejsou } \\
\text { důchody }\end{array}$ \\
\end{tabular} \\
\hline \multicolumn{7}{|l|}{ Sociální } \\
\hline K9 - Závislost na státu & $2 \%$ & 1 & 3 & 4,5 & 4,5 & 2 \\
\hline K10 - Garance minimálního důchodu & $3 \%$ & 4 & 4 & 4 & 2 & 1 \\
\hline $\begin{array}{l}\text { K11 - Zaměstnavatel platí na zaměstnance, } \\
\text { nebo státu }\end{array}$ & $2 \%$ & 2,5 & 2,5 & 2,5 & 5 & 2,5 \\
\hline K12 - Podpora druhého a třetího pilíře státem & $2 \%$ & 3,5 & 3,5 & 3,5 & 3,5 & 1 \\
\hline $\begin{array}{l}\text { K13 - Vyjmutí invalidních, vdovských } \\
\text { a sirotčích dávek z penzijního systému }\end{array}$ & $1 \%$ & 2 & 2 & 2 & 4,5 & 4,5 \\
\hline K14 - Věk odchodu do důchodu & $3 \%$ & 2 & 4 & 4 & 1 & 4 \\
\hline $\begin{array}{c}\text { K15 - Míra závislosti osob v důchodovém } \\
\text { věku na přispěvatelích do systému }\end{array}$ & $3 \%$ & 1,5 & 3 & 5 & 4 & 1,5 \\
\hline K16 - Možnost předčasného důchodu & $3 \%$ & 2 & 2 & 4,5 & 4,5 & 2 \\
\hline K17 - Odměna pro pozdější odchod do důchodu & $2 \%$ & 4,5 & 2 & 4,5 & 2 & 2 \\
\hline K18 - Spořím na sebe, nebo na jiné & $3 \%$ & 1 & 4 & 2,5 & 2,5 & 5 \\
\hline K19 - Diskriminace & $3 \%$ & 4,5 & 2 & 4,5 & 2 & 2 \\
\hline \multirow[t]{3}{*}{ K20 - Závislost výše důchodu na počtu dětí } & $2 \%$ & 2,5 & 2,5 & 2,5 & 2,5 & 5 \\
\hline & & 0,7726778 & 0,87139 & 1,122118 & 0,8817 & 0,7977 \\
\hline & & 5 & 3 & 1 & 2 & 4 \\
\hline
\end{tabular}


Tab. č. 9: Dílčí ohodnocení variant dle přechodových kritérií a vícekriteriální funkce utility

\begin{tabular}{|c|c|c|c|c|c|c|}
\hline Kritéria/Modely & Váhy & $\begin{array}{l}\text { Současný } \\
\text { systém }\end{array}$ & ČSSD & KDU-ČSL & ODS & $\begin{array}{c}\text { Bez dětí nejsou } \\
\text { důchody }\end{array}$ \\
\hline \multicolumn{7}{|l|}{ Přechodové, tedy krátkodobé } \\
\hline $\begin{array}{l}\text { K21 - Nekrácení důchodu současných } \\
\text { důchodců }\end{array}$ & $4 \%$ & 3,5 & 3,5 & 3,5 & 3,5 & 1 \\
\hline K22 - Možnost volby pilírưu, zda ano či ne & $3 \%$ & 4 & 2 & 5 & 2 & 2 \\
\hline $\begin{array}{l}\text { K23 - Možnost volby systému - nový } \\
\text { vs. starý }\end{array}$ & $3 \%$ & 2 & 2 & 4,5 & 4,5 & 2 \\
\hline \multirow[t]{3}{*}{ K24 - Časový horizont pro zavedení } & $4 \%$ & 5 & 2 & 4 & 3 & 1 \\
\hline & & 0,5504586 & 0,36059 & 0,620784 & 0,4779 & 0,21299 \\
\hline & & 2 & 4 & 1 & 3 & 5 \\
\hline
\end{tabular}

